\title{
Tipe Kerusakan Jalan Provinsi dan Penentuan Skala Prioritas Penanganan di Kabupaten Lamongan
}

\section{Type of Damage of Provincial Roads and Determination of Priority Scale for Handling in Lamongan Regency}

\author{
Ari Widayanti ${ }^{1}$, R Endro Wibisono ${ }^{2}$, Cudesi Kartika Sari ${ }^{3}$ \\ ${ }^{1}$ Jurusan Teknik Sipil, Fakultas Teknik, Universitas Negeri Surabaya, Jln. Ketintang Surabaya. Email: \\ ariwidayanti@unesa.ac.id \\ ${ }^{2}$ Jurusan Teknik Sipil, Fakultas Teknik, Universitas Negeri Surabaya, Jln. Ketintang Surabaya. Email: \\ endrowibisono@unesa.ac.id \\ ${ }^{3}$ Jurusan Teknik Sipil, Fakultas Teknik, Universitas Negeri Surabaya, Jln. Ketintang Surabaya. Email: \\ cudesisari@mhs.unesa.ac.id
}

\begin{abstract}
Abstrak
Kerusakan jalan yang terjadi di berbagai daerah saat ini merupakan permasalahan yang kompleks dan menyebabkan kerugian terutama bagi pengguna jalan, seperti waktu tempuh yang lama, kemacetan, kecelakaan lalu lintas dan lain-lain. Jalan Provinsi di Kabupaten Lamongan merupakan jalan penghubung dengan kota Mojokerto, Jombang berupa perkerasan lentur. Berbagai kendaraan berat dan ringan melewati ruas jalan tersebut sehingga menyebabkan kerusakan jalan. Hal ini membutuhkan perhatian khusus dalam penanganan dan pemeliharaan secara rutin kerusakan jalan Provinsi di Kabupaten Lamongan. Tujuan penelitian ini adalah. menentukan skala prioritas dalam penanganan kerusakan jalan Provinsi di Kabupaten Lamongan. Metode yang digunakan dalam penelitian ini adalah metode Pavement Condition Index (PCI), yaitu dengan melakukan analisis perhitungan pada jenis kerusakan jalan yang terjadi. Hal ini diharapkan dapat digunakan sebagai acuan untuk pemeliharaan atau prioritas penanganan jalan di Kabupaten Lamongan. Hasil yang diperoleh adalah penentuan skala prioritas penanganan jalan provinsi di Kabupaten Lamongan berdasarkan penilaian kondisi perkerasan jalan yaitu Jalan Babat - Batas Kabupaten Jombang, Jalan Batas Kota Lamongan - Batas Kabupaten Mojokerto, Jalan Lamong Rejo, Jalan Achmad Dahlan, Jalan Sunan Drajat, Jalan Raya Mantup.
\end{abstract}

Kata Kunci: Skala prioritas; kerusakan jalan; jalan provinsi

\begin{abstract}
Road damage that has occurred in various regions is currently a complex problem and causes losses, especially for road users, such as long travel times, congestion, traffic accidents and others. The provincial road in Lamongan Regency is a connecting road with the city of Mojokerto, Jombang in the form of flexible pavement. Various heavy and light vehicles pass through these roads, causing road damage. This requires special attention in the routine handling and maintenance of damaged provincial roads in Lamongan Regency. The purpose of this research is. determine the priority scale in handling damage to provincial roads in Lamongan Regency. The method used in this research is the Pavement Condition Index (PCI) method, namely by analyzing the calculation of the type of road damage that occurs. It is hoped that this can be used as a reference for maintenance or priority road handling in Lamongan Regency. The results obtained were the determination of the priority scale for handling provincial roads in Lamongan Regency based on the assessment of road pavement conditions, namely Jalan Babat - Jombang District Boundary, Lamongan City Boundary Road Mojokerto Regency Boundary, Jalan Lamong Rejo, Jalan Achmad Dahlan, Jalan Sunan Drajat, Jalan Raya Mantup.
\end{abstract}

Keywords: Priority scale; road damage; provincial road 


\section{PENDAHULUAN}

Prasarana transportasi jalan mempunyai peranan untuk mendorong pembangunan semua wilayah dalam upaya untuk mencapai tingkat perkembangan antar daerah. Prasarana transportasi jalan juga merupakan satu kesatuan sistem jaringan jalan yang mengikat dan menghubungkan pusat - pusat pertumbuhan dengan wilayah lainnya (Risdiansyah: 2014:51). Secara umum penyebab kerusakan jalan diantaranya adalah umur rencana jalan yang dilewati, genangan air pada permukaan jalan yang tidak dapat mengalir akibat drainase yang kurang baik, kelebihan tonase kendaraan yang menyebabkan umur pakai jalan lebih pendek dari umur rencana jalan, perencanaan yang tidak tepat, pengawasan yang kurang baik dan pelaksanaan yang tidak sesuai dengan standar yang ada. Selain itu juga minimnya biaya pemeliharaan, keterlambatan pengeluaran anggaran serta prioritas penanganan yang kurang tepat. Selain itu ketidakdisiplinan pengawasan jalan saat beroperasional merupakan penyebab paling fatal dari kerusakan tersebut.

Kabupaten Lamongan adalah kabupaten di Jawa Timur yang terdiri dari 474 desa yang tersebar di 27 kecamatan yang merupakan kabupaten yang memiliki desa terbanyak di Jawa Timur. Penyediaan transportasi akan menjadi faktor yang sangat penting dalam mendukung kegiatan sehari-hari masyarakat. Transportasi akan membantu mempermudah interaksi antara masyarakat dari desa ke desa lainnya, menghubungkan desa dengan kota pusat pemerintahan. Ketersediaan prasarana dan sarana transportasi yang memadai sangat diperlukan untuk mendukung kegiatan masyarakat, serta perlu adanya penanganan kerusakan jalan yang bisa menghambat kelancaran transportasi. Secara keseluruhan total panjang jalan Kabupaten Lamongan sebesar $346,73 \mathrm{~km}$, terbagi menjadi beberapa kelas jalan dan ruas jalan. Ruas jalan di Kabupaten Lamongan terdiri dari 5 jalan Nasional, 6 jalan Provinsi, 43 jalan Kabupaten. Pada tahun 2011 terdapat jalan rusak sebesar 42,97\%.
Tabel 1. Ruas - Ruas Jalan Provinsi Kabupaten Lamongan Tahun 2015

\begin{tabular}{|c|c|c|c|c|c|c|c|c|}
\hline \multirow[t]{2}{*}{ No } & \multicolumn{5}{|c|}{ No Ruas } & \multirow{2}{*}{\multicolumn{2}{|c|}{$\begin{array}{l}\text { Nama } \\
\text { Ruas }\end{array}$}} & \multirow{2}{*}{$\begin{array}{c}\text { Panjan } \\
\text { g Ruas } \\
(\mathrm{Km})\end{array}$} \\
\hline & & ama & & & Baru & & & \\
\hline 1 & & 2 & & & 3 & & 4 & 5 \\
\hline 1 & 133 & & & 148 & & & $\begin{array}{l}\text { Babat - } \\
\text { Batas. } \\
\text { Kab. } \\
\text { Jombang }\end{array}$ & 30,78 \\
\hline 2 & 134 & 11 & K & 149 & 11 & $\mathrm{~K}$ & $\begin{array}{l}\text { Jln. } \\
\text { Lamong } \\
\text { Rejo }\end{array}$ & 1,06 \\
\hline 3 & 134 & 12 & K & 149 & 12 & K & $\begin{array}{l}\text { Jln. } \\
\text { Achmad } \\
\text { Dahlan }\end{array}$ & 0,09 \\
\hline 4 & 134 & 13 & K & 149 & 13 & & $\begin{array}{l}\text { ln. Sunan } \\
\text { Prajad }\end{array}$ & 0,69 \\
\hline 5 & 134 & 14 & K & 149 & 14 & K & $\begin{array}{l}\text { Jln. Raya } \\
\text { Mantup }\end{array}$ & 2,17 \\
\hline 6 & 134 & & & 149 & & & $\begin{array}{l}\text { Batas. } \\
\text { Kota } \\
\text { Lamonga } \\
\text { n - Batas. } \\
\text { Kab. } \\
\text { Mojo } \\
\text { kerto } \\
\end{array}$ & 21,70 \\
\hline Tota & Panjan & Jalas & & & & & & 56,49 \\
\hline
\end{tabular}

Tabel 2. Kondisi Jalan Provinsi di Kabupaten Lamongan Tahun 2015

\begin{tabular}{|c|c|c|c|c|c|}
\hline \multirow[t]{2}{*}{ No } & \multirow[t]{2}{*}{ Nama Ruas } & \multicolumn{4}{|c|}{ Kondisi Jalan } \\
\hline & & $\begin{array}{l}\text { Baik } \\
(\mathrm{Km} \\
)\end{array}$ & $\begin{array}{c}\text { Sedan } \\
\mathrm{g} \\
(\mathrm{Km})\end{array}$ & $\begin{array}{c}\text { Rusak } \\
\text { Ringa } \\
\mathrm{n} \\
(\mathrm{Km}) \\
\end{array}$ & $\begin{array}{c}\text { Rusa } \\
\text { k } \\
\text { Berat } \\
(\mathrm{Km})\end{array}$ \\
\hline \multirow[t]{2}{*}{1} & Babat $\quad-$ & 3,79 & 17,350 & 9,550 & - \\
\hline & $\begin{array}{l}\text { Batas. Kab. } \\
\text { Jombang }\end{array}$ & 5 & & & \\
\hline \multirow[t]{2}{*}{2} & Jln. & 1,12 & - & - & - \\
\hline & $\begin{array}{l}\text { Lamong } \\
\text { Rejo }\end{array}$ & 0 & & & \\
\hline \multirow[t]{2}{*}{3} & Jln. & 0,07 & - & - & - \\
\hline & $\begin{array}{l}\text { Achmad } \\
\text { Dahlan }\end{array}$ & 0 & & & \\
\hline \multirow[t]{2}{*}{4} & Jln. Sunan & 0,70 & - & - & - \\
\hline & Drajad & 0 & & & \\
\hline \multirow[t]{2}{*}{5} & Jln. Raya & 2,15 & - & - & - \\
\hline & Mantup & 0 & & & \\
\hline \multirow[t]{4}{*}{6} & Batas kota & 8,82 & 2,200 & 10,600 & - \\
\hline & Lamongan & 0 & & & \\
\hline & $\begin{array}{l}- \\
\text { Kab. }\end{array}$ & & & & \\
\hline & Mojokerto & & & & \\
\hline
\end{tabular}

Sumber: UPT Surabaya Dinas PU. Bina Marga Provinsi Jawa Timur 


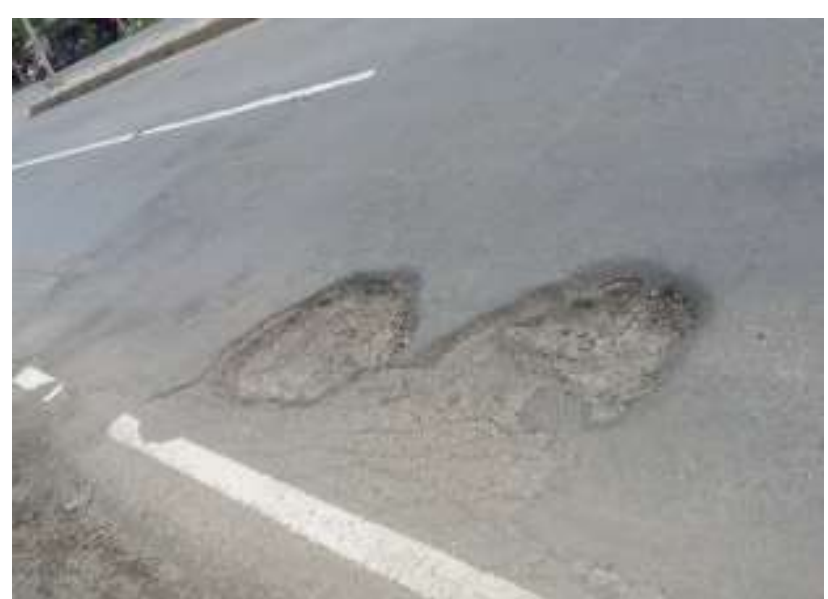

Gambar 1. Jalan Berlubang

Sumber: Hasil Survei 2016

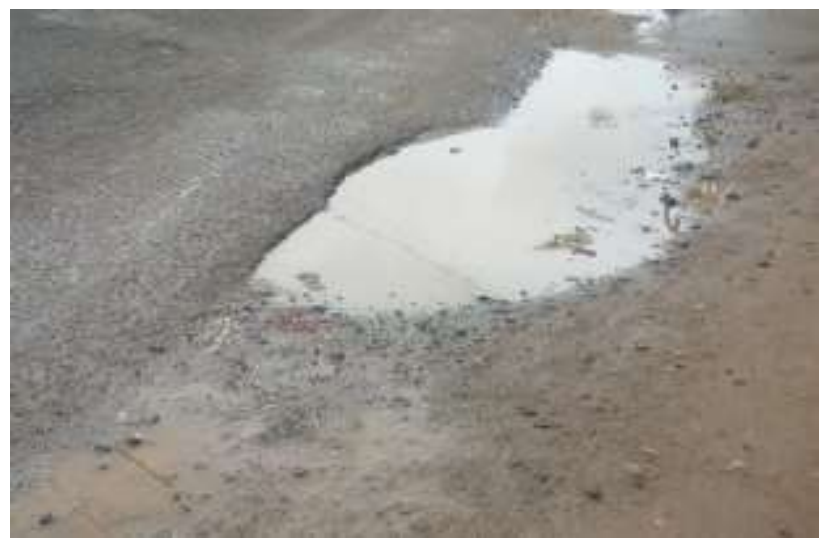

Gambar 2. Jalan Berlubang dan Tergenang Air.

Sumber: Hasil Survei 2016

Ruas jalan Provinsi di Kabupaten Lamongan berupa perkerasan lentur yang merupakan jalan penghubung dengan wilayah Mojokerto dan Jombang. Hal ini perlu mendapat perhatian khusus dalam penanganan dan pemeliharaan secara rutin terkait kerusakan jalan Provinsi di Kabupaten Lamongan.

Berdasarkan latar belakang di atas, maka rumusan masalah yang hendak diselesaikan dalam penelitian ini, yaitu: Bagaimanakah klasifikasi kerusakan jalan Provinsi di Kabupaten Lamongan? Bagaimanakah skala prioritas dalam penanganan kerusakan jalan Provinsi di Kabupaten Lamongan? Bagaimana alternatif penanganan kerusakan jalan Provinsi di Kabupaten Lamongan?

Batasan penelitian mencakup inventarisasi kerusakan jalan, analisis kerusakan jalan dan prioritas penanganan di Kabupaten Lamongan. Data berasal dari Dinas Pekerjaan Umum Provinsi Jawa Timur dan Dinas Pekerjaan Umum Bina Marga Kabupaten Lamongan. Jenis jalan yang dianalisis adalah jalan Provinsi di Kabupaten Lamongan.
Metode menggunakan metode Pavement Condition Index (PCI).

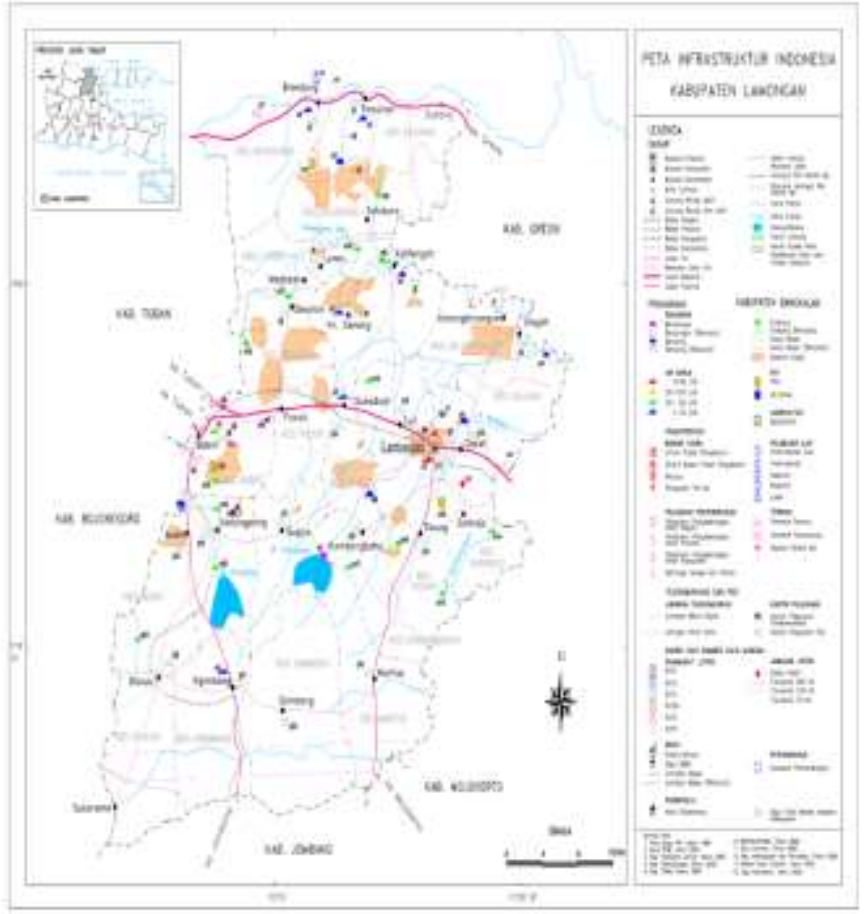

Gambar 3. Peta Wilayah Kabupaten Lamongan.

Sumber: google Kab. Lamongan

Berdasarkan Gambar 3, Kabupaten Lamongan memiliki batas wilayah administratif yaitu berbatasan dengan Kabupaten Jombang dan Kabupaten Mojokerto di sebelah Selatan, dan berbatasan dengan Kabupaten Bojonegoro dan Kabupaten Tuban di sebelah Barat.

\section{METODE PENELITIAN}

Dalam penelitian ini dilakukan pengambilan data dari Dinas P.U Bina Marga Kabupaten Lamongan dan Dinas Pekerjaan Umum Bina Marga Provinsi di Kota Surabaya, serta observasi langsung di lokasi jalan Provinsi di Kabupaten Lamongan, peta Kabupaten Lamongan beserta nama-nama jalan. Selain itu juga literatur-literatur pendukung analisis kerusakan jalan. Setelah mendapatkan data tersebut, maka langkah selanjutnya adalah observasi di lapangan serta mengambil gambar di ruas jalan yang mengalami kerusakan dan mengamati jenis kerusakan tersebut.

Beberapa jenis data beserta foto jenis kerusakan jalan provinsi di Kabupaten Lamongan, dan melakukan pengukuran lebar dan kedalaman kerusakan jalan yang terjadi pada segmen yang mengalami kerusakan, volume lalu lintas harian kendaraan dan pencatatan jenis kerusakan yang terjadi. Kondisi alam dan lingkungan di sekitar ruas jalan di Kabupaten Lamongan. Data Dinas 
Pekerjaan Umum Bina Marga Provinsi Surabaya, jurnal-jurnal serta literatur lainnya. Berikut ini adalah data sekunder yang digunakan yaitu data peta wilayah Kabupaten Lamongan, dama-nama jalan dan panjang ruas jalan, data kerusakan jalan, teori penjelasan terkait kerusakan jalan dari berbagai sumber.

Adapun perlengkapan dan peralatan yang digunakan sebagai berikut: form survei yang terdiri dari form survei kondisi kerusakan jalan, papan alas (clip bpar, alat tulis menulis, jam tangan dan kamera), roll meter.

Tahapan persiapan penelitian meliputi studi literatur dan kepustakaan (menentukan sumber dan jenis data yang dibutuhkan), survei pendahuluan di lapangan, menyiapkan alat - alat dan perlengkapan yang digunakan, mengurus surat perijinan pelaksanaan survei. Tahapan pelaksanaan meliputi pelaksanaan survei, pengumpulan data primer dan sekunder, analisis data, kesimpulan dan rekomendasi.

Metode analisis menggunakan metode Pavement Condition Index (PCI) yaitu dengan melakukan perhitungan analisis pada jenis kerusakan jalan yang terjadi. Nilai PCI memiliki rentang 0 (nol) sampai 100 dengan kriteria sempurna (excellent), sangat baik (very good), baik (good), sedang(fair), jelek (poor), sangat jelek (very poor) dan gagal (failed). Berikut ini diagram nilai PCI beserta alir penelitian.

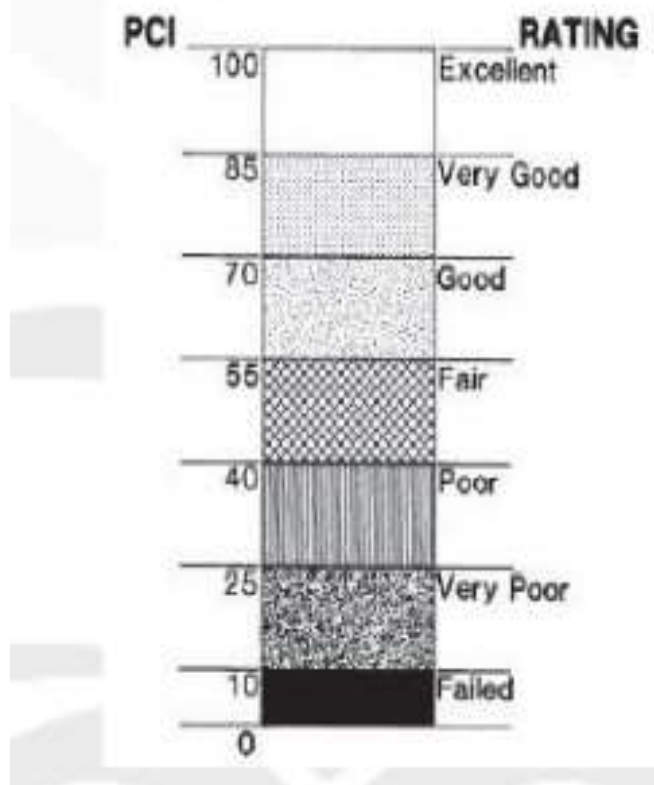

Gambar 4. Diagram Nilai PCI

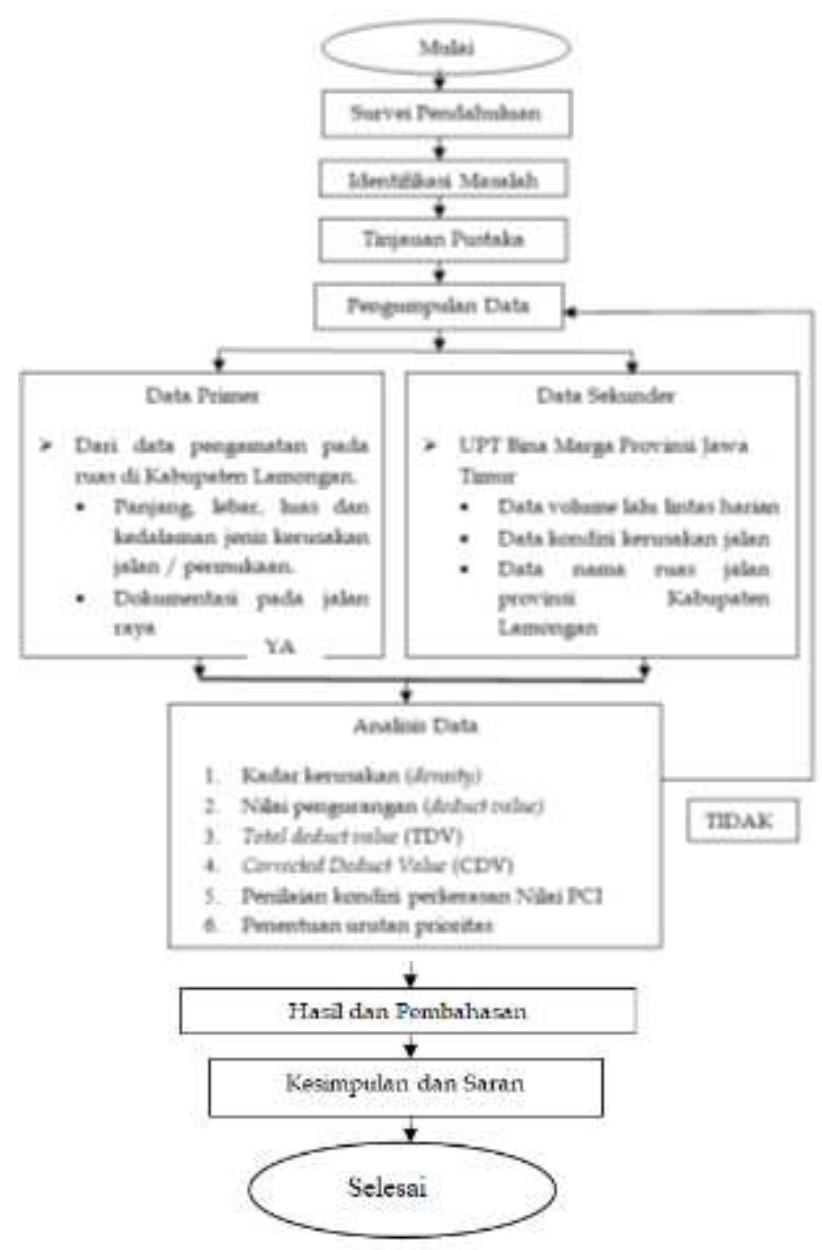

Gambar 5. Diagram Alir Penelitian

\section{HASIL DAN PEMBAHASAN}

Berdasarkan literatur, nilai PCI (Pavement Condition Index) pada masing - masing rating adalah berikut ini:

Tabel 3. PCI (Pavement Condition Index) dan Nilai Kondisi

\begin{tabular}{|c|c|}
\hline Penilaian Kondisi & Rating \\
\hline Sempurna (excellent) & $85-100$ \\
\hline $\begin{array}{l}\text { Sangat baik (very } \\
\text { good) }\end{array}$ & $70-85$ \\
\hline Baik (good) & $55-70$ \\
\hline Sedang (fair) & $40-55$ \\
\hline Jelek (poor) & $25-40$ \\
\hline $\begin{array}{lll}\text { Sangat jelek } & \text { (very } \\
\text { poor) } & & \\
\end{array}$ & $10-25$ \\
\hline Gagal (failed) & $0-10$ \\
\hline
\end{tabular}

Sumber: Shahin,1994

Proteksi/Desember 2020 Volume 2 No. 2 
Hasil observasi kondisi dan kerusakan jalan

Hasil observasi berupa kondisi dan kerusakan jalan yaitu jenis, dimensi, tingkat dan lokasi terjadinya kerusakan. Panjang ruas jalan provinsi di Kabupaten Lamongan sebesar 56,49 km, sehingga untuk melakukan analisis kondisi perkerasan dibagi menjadi 69 segmen. Data kondisi dan kerusakan jalan Provinsi di Kabupaten Lamongan sebagai berikut:

Hasil survei lapangan kondisi kerusakan pada jalan Lamong Rejo dengan panjang 1,06 km dalam table berikut ini.

Tabel 4. Kondisi kerusakan jalan Lamong Rejo

\begin{tabular}{cccc}
\hline No & $\begin{array}{c}\text { Jenis } \\
\text { Kerusakan }\end{array}$ & $\begin{array}{c}\text { Jumlah } \\
\text { Kerusakan }\end{array}$ & $\begin{array}{c}\text { Persentase } \\
(\boldsymbol{\%})\end{array}$ \\
\hline 1 & Retak pinggir & 3 & $100 \%$ \\
\hline & Total & $\mathbf{3}$ & $\mathbf{1 0 0 \%}$
\end{tabular}

Sumber: Hasil Analisis (2016)

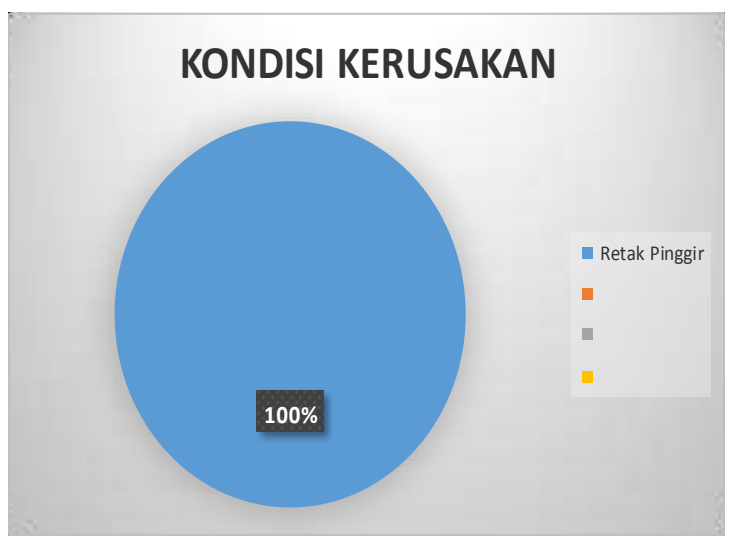

Gambar 6. Kondisi Kerusakan Jalan Lamong Rejo Sumber: Hasil Analisis (2016)

Berdasarkan Gambar 6 diketahui bahwa Jln. Lamong Rejo dengan panjang jalan 1,06 km dengan 4 segmen terdapat 3 kerusakan jalan yaitu retak pinggir dengan persentase kondisi kerusakan jalan sebesar $100 \%$. Kondisi jalan pada Jalan Lamong Rejo sudah baik.

Hasil survei lapangan kondisi kerusakan pada jalan Achmad Dahlan dengan panjang 0,09 km dalam tabel berikut ini.

Tabel 5. Kondisi kerusakan jalan Achmad Dahlan

\begin{tabular}{cccc}
\hline No & $\begin{array}{c}\text { Jenis } \\
\text { Kerusakan }\end{array}$ & $\begin{array}{c}\text { Jumlah } \\
\text { Kerusakan }\end{array}$ & $\begin{array}{c}\text { Presentase } \\
(\boldsymbol{\%})\end{array}$ \\
\hline 1 & Retak pinggir & 2 & $100 \%$ \\
\hline & Total & $\mathbf{2}$ & $\mathbf{1 0 0 \%}$ \\
\hline
\end{tabular}

Sumber: Hasil Analisis (2016)

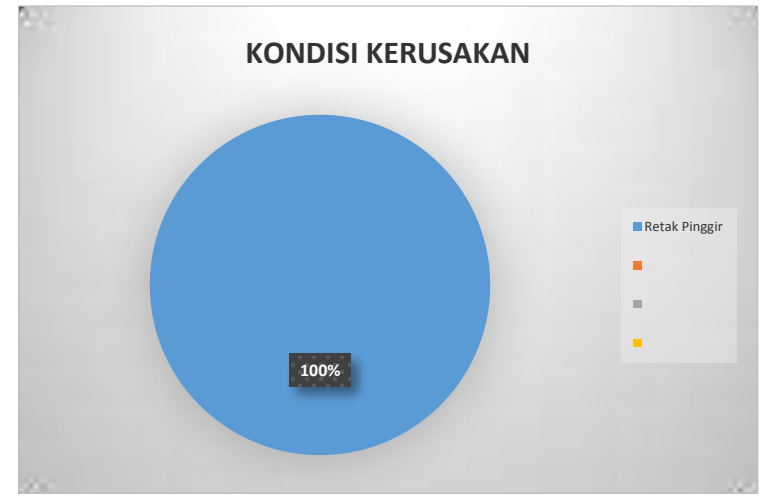

Gambar 7. Kondisi Kerusakan Jalan Achmad Dahlan

Berdasarkan Gambar 7 diperoleh Jalan Achmad Dahlan dengan panjang jalan $0,90 \mathrm{~km}$ dengan 2 Segmen terdapat beberapa kerusakan jalan yaitu pada terdapat $2(100 \%)$ Retak Pinggir dan pada KM $0+090$ terdapat retak pinggir, sehingga dapat diketahui bahwa kondisi kerusakan jalan pada Jln. Achmad Dahlan adalah baik.

Hasil survei lapangan kondisi kerusakan pada jalan Sunan Drajat dengan panjang $0,69 \mathrm{~km}$ adalah sebagai berikut:

Tabel 6. Kondisi kerusakan jalan Sunan Drajat

\begin{tabular}{clcc}
\hline No & $\begin{array}{c}\text { Jenis } \\
\text { Kerusakan }\end{array}$ & $\begin{array}{c}\text { Jumlah } \\
\text { Kerusakan }\end{array}$ & $\begin{array}{c}\text { Presentase } \\
(\%)\end{array}$ \\
\hline 1 & Retak kulit & 6 & $60 \%$ \\
& buaya & & \\
2 & Tambalan & 2 & $20 \%$ \\
3 & Retak pinggir & 1 & $10 \%$ \\
4 & Lubang & 1 & $10 \%$ \\
Total & & 8 & $100 \%$ \\
\hline
\end{tabular}

Sumber: Hasil Analisis (2016)

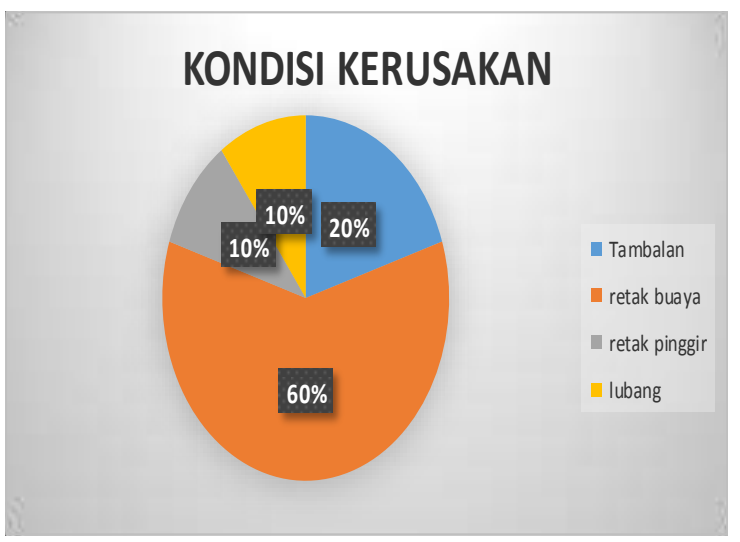

Gambar 8. Kondisi Kerusakan Jalan Sunan Drajat Sumber: Hasil Analisis (2016) 
Berdasarkan Gambar 8 diperoleh beberapa kerusakan jalan dengan panjang jalan 0,69 km, 2 segmen jalan, seperti kerusakan jalan tambalan terdapat 2 dengan presentase $20 \%$ titik kerusakan pada KM $0+350$, kerusakan retak pinggir $1(10 \%)$ dan titik, kerusakan retak buaya adalah $6(60 \%)$ dan 1 titik kerusakan jalan yang berlubang dengan presentase $10 \%$. Berdasarkan hal ini kondisi kerusakan pada Jalan Sunan Drajat adalah sedang.

Hasil survei lapangan kondisi kerusakan pada jalan Lamong Rejo dengan panjang 1,06 km adalah sebagai berikut:

Tabel 7. Kondisi kerusakan jalan Raya Mantup

\begin{tabular}{|c|c|c|c|}
\hline No & $\begin{array}{c}\text { Jenis } \\
\text { Kerusakan }\end{array}$ & $\begin{array}{c}\text { Jumlah } \\
\text { Kerusakan }\end{array}$ & $\begin{array}{l}\text { Presenta } \\
(\%)\end{array}$ \\
\hline 1 & Tambalan & 1 & $17 \%$ \\
\hline 2 & Retak pinggir & 2 & $33 \%$ \\
\hline 3 & Lubang & 2 & $33 \%$ \\
\hline \multirow[t]{4}{*}{4} & $\begin{array}{l}\text { Retak } \\
\text { memanjang/ } \\
\text { Melintang }\end{array}$ & 1 & $17 \%$ \\
\hline & Total & 6 & $100 \%$ \\
\hline & KONDISI & ERUSAKAN & \\
\hline & $33 \%$ & $\begin{array}{l}\text { " Lubang } \\
\text { " retak m } \\
\text { " tambala } \\
\text { " r retak pi }\end{array}$ & ang/melintang \\
\hline
\end{tabular}

Gambar 9. Kondisi Kerusakan Jalan Raya Mantup

Berdasarkan Gambar 9, diperoleh kondisi kerusakan jalan di Jalan Raya Mantup terdapat beberapa kerusakan jalan yaitu kerusakan jalan berlubang sebesar 33\%, terdapat kerusakan jalan Retak memanjang/melintang yaitu $17 \%$, dan kerusakan retak pinggir dengan persentase $33 \%$ serta kerusakan jalan tambalan sebesar 17\%. Pada Jln. Raya Mantup panjang jalan 2,17 km dengan 5 segmen dan panjang setiap segmen adalan $500 \mathrm{~m}$.

\section{Perhitungan PCI (Pavement Condition Index)}

Hasil akhir penilaian metode PCI adalah berupa nilai PCI. Nilai pengurangan dimiliki oleh setiap jenis kerusakan yang didapatkan dari kurva hubungan antara persentase kerusakan dalam sebuah segmen yang ditinjau. Berikut ini merupakan contoh untuk perhitungan nilai pengurangan ruas jalan Babat - Batas Kabupaten Jombang dengan 30 segmen.

Pada data kerusakan STA $1+1000$

Berlubang = luas kerusakan $3 \mathrm{~m}^{2}$

$$
\text { Kerapatan (density)\% }
$$

$$
=\quad \frac{A d}{A s} \times 100 \%
$$

$=\frac{3}{7000} \times 100 \%=0,042 \%$

- $\quad$ Tambalan = luas kerusakan $1 \mathrm{~m}^{2}$ Hitung kerapatan (density\%)

$$
\begin{gathered}
=\frac{A d}{A s} \times 100 \% \\
=\frac{1}{7000} \times 100 \%=0,14 \%
\end{gathered}
$$

- Butiran lepas $=$ luas kerusakan $0,5 \mathrm{~m}^{2}$

Hitung kerapatan (density \%)

$$
\begin{aligned}
& =\frac{A d}{A s} \times 100 \% \\
& \frac{0,5}{7000} \times 100 \%=0,007 \%
\end{aligned}
$$

- Retak Kulit buaya = luas kerusakan 0,003 $\mathrm{m}^{2}$ Hitung kerapatan (density \%)

$$
\begin{aligned}
& =\frac{A d}{A s} \times 100 \% \\
& \frac{0.003}{7000} \times 100 \%=0,0004 \%
\end{aligned}
$$

- Rusak perpotongan rel $=$ luas kerusakan 0,003 $\mathrm{m}^{2}$

$$
\begin{aligned}
& \text { Hitung kerapatan (density\%) } \\
& =\frac{A d}{A s} \times 100 \% \\
& \frac{0.003}{7000} \times 100 \%=0,0004 \%
\end{aligned}
$$


Berdasarkan Gambar 10 diperoleh deduct value untuk jenis kerusakan lubang didapatkan nilai deduct value berdasarkan nilai density 0,042 \% dengan tingkat kerusakan Medium (M) adalah 19.

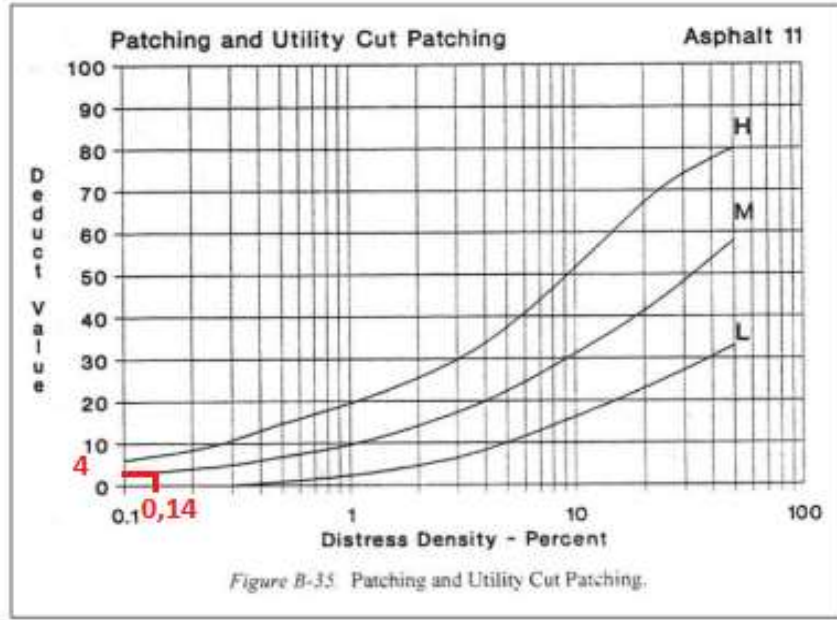

Gambar 11. Grafik Kerusakan Tambalan

Sumber: Hasil Analisis (2016)

Berdasarkan Gambar 11 pada kerusakan tambalan didapatkan nilai deduct value untuk nilai density $0,14 \%$ dengan tingkat keruskan Medium (M) adalah 4.

Tabel 8. Hasil Analisis Kondisi Kerusakan Jalan Lamong Rejo

\begin{tabular}{|c|c|c|c|c|c|c|c|}
\hline \multirow{2}{*}{$\begin{array}{c}\text { STA. } \\
\text { KM }\end{array}$} & \multicolumn{2}{|c|}{ Posisi } & \multirow{2}{*}{$\begin{array}{c}\text { Distr } \\
\text { ess } \\
\text { Seve } \\
\text { nty } \\
\end{array}$} & \multirow{2}{*}{$\begin{array}{l}\text { Qua } \\
\text { lity } \\
\left(\mathbf{m}^{2}\right)\end{array}$} & \multirow{2}{*}{$\begin{array}{c}\text { Total } \\
\left(\mathbf{m}^{2}\right)\end{array}$} & \multirow{2}{*}{$\begin{array}{l}\text { Den } \\
\text { sity } \\
(\%)\end{array}$} & \multirow{2}{*}{$\begin{array}{c}\text { Deduct } \\
\text { Value }\end{array}$} \\
\hline & $\begin{array}{l}\mathbf{K i} \\
\mathbf{r i}\end{array}$ & $\begin{array}{l}\text { Ka } \\
\text { nan }\end{array}$ & & & & & \\
\hline $0+$ & & & & 0,01 & & & \\
\hline 250 & $\sqrt{ }$ & & $7 \mathrm{H}$ & 2 & 0,012 & 0,57 & 8 \\
\hline $0+$ & & & & 0,02 & & 0,10 & \\
\hline 550 & & $\sqrt{ }$ & $7 \mathrm{M}$ & 2 & 0,022 & 5 & 17 \\
\hline $0+$ & & & & 0,03 & & 0,17 & \\
\hline 700 & & $\sqrt{ }$ & $7 \mathrm{M}$ & 7 & 0,037 & 7 & 20 \\
\hline $1+$ & & & & & & & \\
\hline 006 & & - & - & - & - & - & - \\
\hline
\end{tabular}

Sumber: Hasil Analisis (2016)

Tabel 9. Hasil Analisis Kondisi Kerusakan Jalan Achmad Dahlan

\begin{tabular}{|c|c|c|c|c|c|c|c|}
\hline \multirow{2}{*}{$\begin{array}{c}\text { STA } \\
\text { KM }\end{array}$} & \multicolumn{2}{|c|}{ Posisi } & \multirow{2}{*}{$\begin{array}{l}\text { Dist } \\
\text { ress } \\
\text { Sev } \\
\text { enty }\end{array}$} & \multirow{2}{*}{$\begin{array}{c}\text { Qua } \\
\text { lity } \\
\text { (m2) }\end{array}$} & \multirow{2}{*}{$\begin{array}{l}\text { Total } \\
(\mathrm{m} 2)\end{array}$} & \multirow{2}{*}{$\begin{array}{l}\text { Den } \\
\text { sity } \\
(\%)\end{array}$} & \multirow{2}{*}{$\begin{array}{l}\text { Deduct } \\
\text { Value }\end{array}$} \\
\hline & $\begin{array}{l}\mathrm{K} \\
\text { iri } \\
\end{array}$ & $\begin{array}{l}\text { Ka } \\
\text { nan }\end{array}$ & & & & & \\
\hline $0+$ & & & & 0,00 & & & 11 \\
\hline 000 & $\sqrt{ }$ & & $7 \mathrm{H}$ & 21 & 0,0021 & 2,8 & \\
\hline & & & & 0,09 & & & 6 \\
\hline & $\sqrt{ }$ & & $7 \mathrm{M}$ & 9 & 0,099 & 1,32 & \\
\hline $0+$ & & & & 0,04 & & & 46 \\
\hline 009 & $\sqrt{ }$ & & $7 \mathrm{H}$ & 6 & 0,046 & 61,3 & \\
\hline
\end{tabular}

Jumlah total value deduct

Sumber: Hasil Analisis (2016)
Tabel 10. Hasil Analisis Kondisi Kerusakan Jalan Sunan Drajat

\begin{tabular}{|c|c|c|c|c|c|c|c|}
\hline \multirow{2}{*}{$\begin{array}{c}\text { STA } \\
\text { KM }\end{array}$} & \multicolumn{2}{|c|}{ Posisi } & \multirow{2}{*}{$\begin{array}{c}\text { Distr } \\
\text { ess } \\
\text { Seven } \\
\text { ty } \\
\end{array}$} & \multirow{2}{*}{$\begin{array}{l}\text { Qua } \\
\text { lity } \\
\text { (m2) }\end{array}$} & \multirow{2}{*}{$\begin{array}{l}\text { Total } \\
\text { (m2) }\end{array}$} & \multirow{2}{*}{$\begin{array}{c}\text { Density } \\
(\%)\end{array}$} & \multirow{2}{*}{$\begin{array}{c}\text { Deduct } \\
\text { Value }\end{array}$} \\
\hline & $\begin{array}{l}\mathbf{K i} \\
\mathbf{r i}\end{array}$ & $\begin{array}{l}\text { Ka } \\
\text { nan }\end{array}$ & & & & & \\
\hline \multirow[t]{4}{*}{$\begin{array}{ll}0 & + \\
350\end{array}$} & $\sqrt{ }$ & & $11 \mathrm{M}$ & 3 & 3 & 8,57 & 11 \\
\hline & $\sqrt{ }$ & & $11 \mathrm{H}$ & 4 & 4 & 11,4 & 13 \\
\hline & & $\sqrt{ }$ & $7 \mathrm{M}$ & $\begin{array}{l}0,01 \\
7 \\
\end{array}$ & 0,017 & 0,048 & - \\
\hline & $\sqrt{ }$ & & $1 \mathrm{~L}$ & 0,01 & 0,01 & 0,028 & - \\
\hline \multirow[t]{6}{*}{$\begin{array}{ll}0 \quad+ \\
690\end{array}$} & $\sqrt{ }$ & & $1 \mathrm{~L}$ & 0,09 & 0,09 & 0,23 & 5 \\
\hline & $\sqrt{ }$ & & $1 \mathrm{~L}$ & $\begin{array}{l}0,05 \\
5\end{array}$ & 0,055 & 0,14 & 5 \\
\hline & & $\sqrt{ }$ & $1 \mathrm{~L}$ & 0,06 & 0,06 & 0,15 & 5 \\
\hline & $\sqrt{ }$ & & $1 \mathrm{~L}$ & 0,02 & 0,02 & 0,051 & - \\
\hline & $\sqrt{ }$ & & $1 \mathrm{~L}$ & $\begin{array}{l}0,03 \\
3 \\
\end{array}$ & 0,033 & 0,084 & - \\
\hline & $\sqrt{ }$ & & $13 \mathrm{~L}$ & $\begin{array}{l}0,13 \\
8\end{array}$ & 0,138 & 0,35 & 40 \\
\hline Total & umls & Dedu & Value & & & & 79 \\
\hline
\end{tabular}

Sumber: Hasil Analisis (2016)

Tabel 11. Hasil Analisis Kondisi Kerusakan Jalan Raya Mantup

\begin{tabular}{|c|c|c|c|c|c|c|c|}
\hline $\begin{array}{l}\text { STA } \\
\text { KM }\end{array}$ & $\begin{array}{l}\text { Posisi } \\
\mathrm{Ki} \\
\text { ri }\end{array}$ & $\begin{array}{l}\mathrm{Ka} \\
\text { nan }\end{array}$ & $\begin{array}{l}\text { Distre } \\
\text { ss } \\
\text { Seven } \\
\text { ty }\end{array}$ & $\begin{array}{l}\text { Qual } \\
\text { ity } \\
(\mathrm{m} 2 \\
)\end{array}$ & $\begin{array}{l}\text { Total } \\
(\mathrm{m} 2)\end{array}$ & $\begin{array}{l}\text { Density } \\
(\%)\end{array}$ & $\begin{array}{l}\text { Deduct } \\
\text { Value }\end{array}$ \\
\hline $\begin{array}{c}0+ \\
500\end{array}$ & $\sqrt{ }$ & & $11 \mathrm{~L}$ & 0,06 & 0,06 & 0,096 & 2 \\
\hline & & $\sqrt{ }$ & $7 \mathrm{H}$ & 0,05 & 0,05 & 0,08 & 2 \\
\hline $\begin{array}{c}1+ \\
000\end{array}$ & $\sqrt{ }$ & & $13 \mathrm{~L}$ & 0,01 & 0,01 & 0,016 & 5 \\
\hline$\underset{500}{1+}$ & $\sqrt{ }$ & & $10 \mathrm{H}$ & 0,12 & 0,12 & 0,19 & 3 \\
\hline $\begin{array}{c}2+ \\
000 \\
\end{array}$ & $\sqrt{ }$ & & $13 \mathrm{~L}$ & $\begin{array}{l}0,01 \\
2 \\
\end{array}$ & 0,012 & 0,019 & 6 \\
\hline $\begin{array}{c}2+ \\
017\end{array}$ & & $\sqrt{ }$ & $7 \mathrm{~L}$ & $\begin{array}{l}0,01 \\
8 \\
\end{array}$ & 0,018 & 0,028 & - \\
\hline
\end{tabular}

Total Jumlah Deduct Value

18

Sumber: Hasil Analisis (2016)

\section{Nilai Pengurang Total / Total Deduct Value}

Nilai Correct Deduct Value (CDV) sangat diperlukan untuk mendapatkan nilai PCI dan didapatkan dari sebuah kurva hubungan antara TDV dan q. Terdapat beberapa langkah yang harus dilakukan untuk mendapatkan nilai CDV. Berikut ini merupakan langkah - langkah untuk mendapatkan nilai CDV. 
Tabel 12. Nilai Corrected Deduct Value Dan Nilai PCI Segmen Untuk Ruas Jalan Lamong Rejo

\begin{tabular}{ccccc}
\hline $\begin{array}{c}\text { Seg } \\
\text { men }\end{array}$ & STA. KM & $\begin{array}{c}\text { Total } \\
\text { Deduct } \\
\text { Value } \\
\text { (TDV) }\end{array}$ & $\begin{array}{c}\text { Correcte } \\
\text { d Deduct } \\
\text { Value } \\
\text { (CDV) }\end{array}$ & $\begin{array}{c}\text { Nilai PCI (1 } \\
\text { - CDV) }\end{array}$ \\
\hline 1 & $0+250$ & 8 & 8 & 92 \\
2 & $0+500$ & 17 & 19 & 71 \\
3 & $0+750$ & 20 & 20 & 80 \\
4 & $1+007$ & 0 & 0 & 0 \\
& Total Nilai PCI & & $\mathbf{2 4 3}$
\end{tabular}

Sumber: Hasil Analisis (2016)

Dari Tabel 12 diperoleh total nilai PCI adalah 243, sehingga dapat dicari nilai PCI rata - rata untuk jalan Lamong Rejo, sebagai berikut:

$$
\begin{gathered}
P C I=\frac{\text { total nilai PCI }}{\text { Jumlah segmen jalan }} \\
\text { PCI }=\frac{243}{4}=60,75 \text { (Baik) }
\end{gathered}
$$

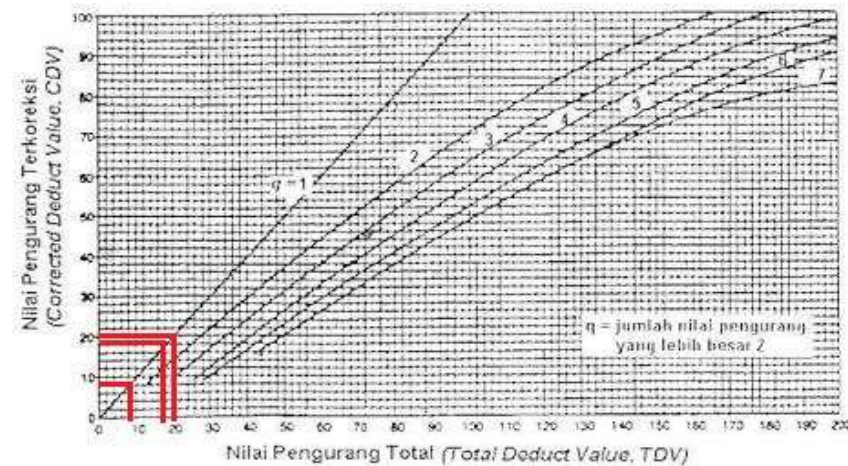

Gambar 12. Ploting Nilai CDV Jalan Lamong Rejo Sumber: Hasil Analisis (2016)

Tabel 13. Nilai Corrected Deduct Value Dan Nilai PCI Segmen Untuk Ruas Jalan Achmad Dahlan

\begin{tabular}{ccccc}
\hline Segmen & $\begin{array}{c}\text { STA. } \\
\text { KM }\end{array}$ & $\begin{array}{c}\text { Total } \\
\text { Deduct } \\
\text { Value } \\
\text { (TDV) }\end{array}$ & $\begin{array}{c}\text { Correcte } \\
\text { d Deduct } \\
\text { Value } \\
\text { (CDV) }\end{array}$ & $\begin{array}{c}\text { Nilai } \\
\text { PCI } \\
(\mathbf{1 0 0}- \\
\text { CDV) }\end{array}$ \\
\hline 1 & $0+000$ & 17 & 18 & 82 \\
2 & $0+009$ & 46 & 34 & 66 \\
& \multicolumn{2}{c}{ Total Nilai PCI } & & $\mathbf{1 4 8}$ \\
\hline
\end{tabular}

Sumber: Hasil Analisis (2016)

Dari tabel diatas dapat dilihat bawah total nilai PCI adalah 148. Sehingga dapat dicari nilai PCI rata rata untuk jalan Achmad Dahlan, sebagai berikut $P C I=\frac{\text { total nilai } P C I}{\text { Jumlah segmen jalan }}$

$$
P C I=\frac{148}{2}=74(\text { Sangat Baik })
$$

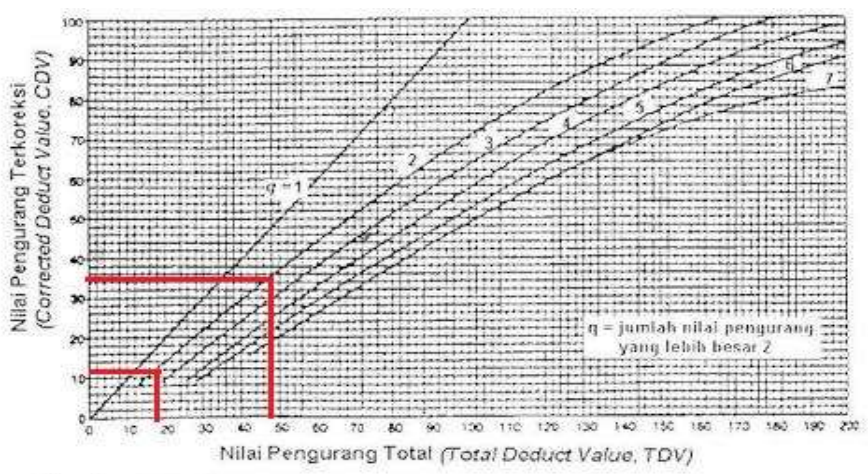

Gambar 13. Ploting Nilai CDV Jalan Achmad Dahlan

Sumber: Hasil Analisis (2016)

Tabel 14. Nilai Corrected Deduct Value Dan Nilai PCI Segmen Untuk Ruas Jalan Sunan Drajat

\begin{tabular}{clccc}
\hline Segmen & $\begin{array}{c}\text { STA. } \\
\text { KM }\end{array}$ & $\begin{array}{c}\text { Total } \\
\text { Deduct } \\
\text { Value } \\
\text { (TDV) }\end{array}$ & $\begin{array}{c}\text { Correc } \\
\text { ted } \\
\text { Deduct } \\
\text { Value } \\
\text { (CDV) }\end{array}$ & $\begin{array}{c}\text { Nilai } \\
\text { PCI } \\
(\mathbf{1 0 0} \\
\text { CDV) }\end{array}$ \\
\hline 1 & $0+350$ & 24 & 18 & 82 \\
2 & $0+690$ & 55 & 30 & 70 \\
& Total Nilai PCI & & $\mathbf{1 5 2}$
\end{tabular}

Sumber: Hasil Analisis (2016)

Dari Tabel 14 diperoleh total nilai PCI adalah 152, sehingga dapat dicari nilai PCI rata - rata untuk jalan Sunan Drajat, sebagai berikut:

$$
\text { PCI }=\frac{\text { total nilai } P C I}{\text { Jumlah segmen jalan }}
$$

$$
\text { PCI }=\frac{152}{2}=76 \text { (Sangat Baik) }
$$

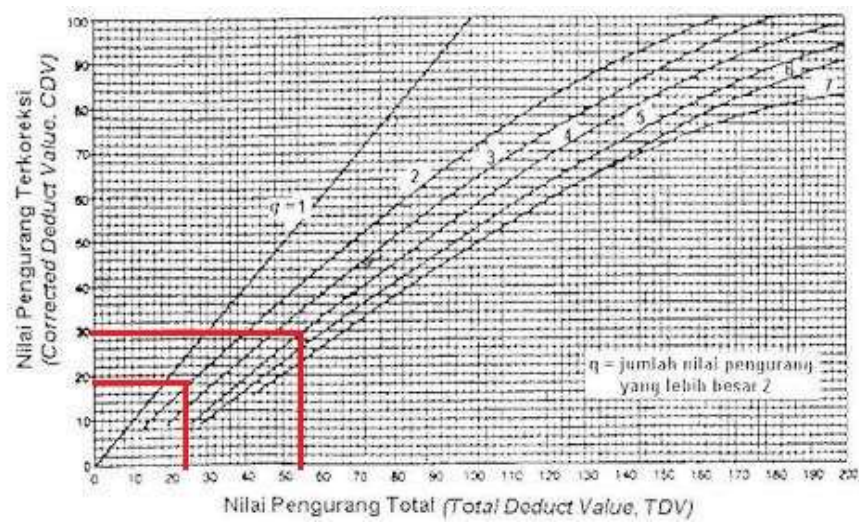

Gambar 14. Ploting CDV jalan Sunan Drajat Sumber: Hasil Analisis (2016) 
Tabel 15. Nilai Corrected Deduct Value Dan Nilai PCI Segmen Untuk Ruas Jalan Raya Mantup

\begin{tabular}{ccccc}
\hline Segmen & $\begin{array}{c}\text { STA. } \\
\text { KM }\end{array}$ & $\begin{array}{c}\text { Total } \\
\text { Deduct } \\
\text { Value } \\
\text { (TDV) }\end{array}$ & $\begin{array}{c}\text { Corrected } \\
\text { Deduct } \\
\text { Value } \\
\text { (CDV) }\end{array}$ & $\begin{array}{c}\text { Nilai } \\
\text { PCI (100 } \\
- \text { CDV) }\end{array}$ \\
\hline 1 & $0+500$ & 4 & 4 & 96 \\
2 & $1+000$ & 5 & 5 & 95 \\
3 & $1+500$ & 3 & 3 & 97 \\
4 & $2+000$ & 6 & 6 & 94 \\
5 & $2+017$ & 0 & 0 & 0 \\
& \multicolumn{2}{c}{ Total Nilai PCI } & & $\mathbf{3 8 2}$
\end{tabular}

Sumber: Hasil Analisis (2016)

Dari Tabel 15 diperoleh total nilai PCI adalah 382, sehingga dapat dicari nilai PCI rata - rata untuk jalan Raya Mantup, sebagai berikut:

$$
P C I=\frac{\text { total nilai } P C I}{\text { Jumlah segmen jalan }}
$$

$P C I=\frac{382}{5}=76,4$ (Sangat baik)

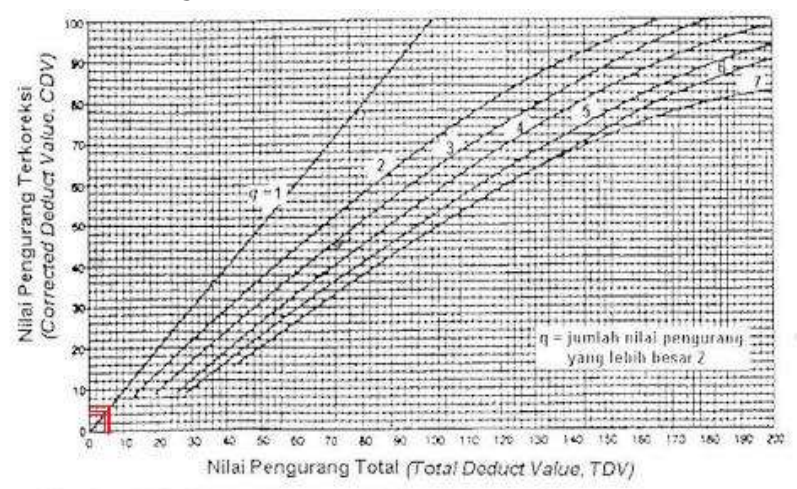

Gambar 15. Ploting Nilai CDV Jalan Raya Mantup Sumber: Hasil Analisis (2016)

\section{Klasifikasi Jenis Kerusakan Jalan Provinsi di Kabupaten Lamongan}

Berikut ini adalah klasifikasi jenis kerusakan pada jalan Provinsi di Kabupaten Lamongan.

Tabel 16.Klasifikasi Jenis Kerusakan Jalan Provinsi

\begin{tabular}{|c|c|c|c|c|}
\hline No & $\begin{array}{l}\text { Klasifikasi Jenis } \\
\text { Kerusakan }\end{array}$ & $\begin{array}{c}\text { Jumlah } \\
\text { Kerusakan }\end{array}$ & $\begin{array}{c}\text { Presen } \\
\text { tase } \\
(\%)\end{array}$ & Kondisi \\
\hline \multirow[t]{7}{*}{1} & Deformasi & & & \\
\hline & a. Alur & 2 & $0,98 \%$ & $\mathbf{L}$ \\
\hline & b.Ambles & 9 & $4,43 \%$ & $\mathrm{~L}$ \\
\hline & c. Sungkur & - & - & - \\
\hline & d. Mengembang & 5 & $2,46 \%$ & $\mathrm{~L}$ \\
\hline & e. Benjol dan Turun & - & - & - \\
\hline & d. Gelombang & - & - & - \\
\hline 2 & $\begin{array}{l}\text { Retak } \\
\text { a. Retak } \\
\quad \text { Buaya }\end{array}$ & 58 & $\begin{array}{c}28,57 \\
\%\end{array}$ & $\mathrm{H}$ \\
\hline
\end{tabular}

\begin{tabular}{|c|c|c|c|c|}
\hline No & $\begin{array}{l}\text { Klasifikasi Jenis } \\
\text { Kerusakan }\end{array}$ & $\begin{array}{c}\text { Jumlah } \\
\text { Kerusakan }\end{array}$ & $\begin{array}{c}\text { Presen } \\
\text { tase } \\
(\%)\end{array}$ & Kondisi \\
\hline & $\begin{array}{l}\text { b. Retak } \\
\text { Melintang/Mema } \\
\text { njang }\end{array}$ & 14 & $6,89 \%$ & $\mathrm{~L}$ \\
\hline & c. Retak Blok & 3 & $1,47 \%$ & $\mathrm{~L}$ \\
\hline & $\begin{array}{l}\text { d.Retak Reflek. } \\
\text { Sambungan }\end{array}$ & - & - & - \\
\hline & e. Retak Slip & - & - & - \\
\hline 3 & $\begin{array}{l}\text { Kerusakan di Pinggir } \\
\text { a. Retak Pinggir }\end{array}$ & 33 & $\begin{array}{c}16,25 \\
\%\end{array}$ & M \\
\hline & b. Jalur/Bahu turun & 11 & $5,41 \%$ & $\mathrm{~L}$ \\
\hline 4 & Kerusakan Tekstur Pe & mukaan & & \\
\hline & a. Butiran Lepas & 7 & $3,44 \%$ & $\mathrm{~L}$ \\
\hline & b. Kegemukan & 1 & $0,49 \%$ & $\mathrm{~L}$ \\
\hline & c. Agregrat Licin & - & - & - \\
\hline 5 & Lubang & 48 & $\begin{array}{c}23,64 \\
\%\end{array}$ & $\mathrm{H}$ \\
\hline 6 & Tambalan & 11 & $5,41 \%$ & $\mathrm{~L}$ \\
\hline 7 & $\begin{array}{l}\text { Persilangan Jalan } \\
\text { Rel }\end{array}$ & 1 & $0,49 \%$ & $\mathrm{~L}$ \\
\hline & Total & 203 & 100 & \\
\hline
\end{tabular}

Sumber: Hasil Analisis (2016)

Berdasarkan Tabel 16 diperoleh klasifikasi kerusakan jalan provinsi berdasarkan jumlah kerusakan jalan yang paling dominan di Kabupaten Lamongan adalah retak kulit buaya sebanyak 58 dengan persentase $28,57 \%$ dan kondisi rusak berat, dan kondisi rusak sedang yang paling dominan adalah retak pinggir dengan jumlah kerusakan 33 dan persentase $16,25 \%$, serta kondisi rusak sedang adalah kegemukan dan persilangan jalan rel dengan jumlah kerusakan 1 dan persentase $0,49 \%$.

\section{Skala Prioritas dalam Penanganan Kerusakan Jalan Provinsi di Kabupaten Lamongan}

Hasil akhir dari analisis PCI untuk tiap jenis unit segmen dan Nilai PCI rata-rata (nilai kondisi perkerasan) dapat dilihat dalam tabel berikut:

Tabel 17. Nilai PCI Tiap Segmen Dan PCI RataRata Jalan Lamong Rejo

\begin{tabular}{ccc}
\hline No & Unit Segmen $(\mathbf{K m})$ & PCI \\
\hline 1 & $0+250$ & 92 \\
2 & $0+500$ & 71 \\
3 & $0+750$ & 80 \\
4 & $1+007$ & 0 \\
\multicolumn{2}{c}{ Rata-rata PCI $=$ Total Nilai } & $\mathbf{2 4 3}$ \\
PCI/Jumlah Segmen & $\mathbf{6 0 , 7 5}$ \\
\hline
\end{tabular}

Sumber: Hasil Analisis (2016)

Tabel 18. Nilai PCI Tiap Segmen Dan PCI RataRata Jalan Achmad Dahlan

\begin{tabular}{ccc}
\hline No & Unit Segmen $(\mathbf{K m})$ & PCI \\
\hline 1 & $0+000$ & 82 \\
2 & $0+009$ & 66 \\
& Jumlah & $\mathbf{1 4 8}$ \\
Rata-rata PCI = Total Nilai & $\mathbf{7 4}$ \\
PCI/Jumlah Segmen &
\end{tabular}

Sumber: Hasil Analisis (2016) 
Tabel 19. Nilai PCI Tiap Segmen Dan PCI RataRata Jalan Sunan Drajat

\begin{tabular}{|c|c|c|}
\hline No & Unit Segmen (Km) & PCI \\
\hline 1 & $0+350$ & 82 \\
\hline \multirow[t]{2}{*}{2} & $0+690$ & 70 \\
\hline & Jumlah & 152 \\
\hline \multicolumn{2}{|c|}{$\begin{array}{l}\text { Rata-rata PCI = Total Nilai } \\
\text { PCI/Jumlah Segmen }\end{array}$} & 76 \\
\hline
\end{tabular}

Sumber: Hasil Analisis (2016)

Tabel 20. Nilai PCI Tiap Segmen Dan PCI RataRata Jalan Raya Mantup

\begin{tabular}{ccc}
\hline No & $\begin{array}{c}\text { Unit Segmen } \\
(\mathbf{K m})\end{array}$ & PCI \\
\hline 1 & $0+500$ & 96 \\
2 & $1+000$ & 95 \\
3 & $1+500$ & 97 \\
4 & $2+000$ & 94 \\
5 & $2+017$ & 0 \\
\multicolumn{2}{c}{ Jumlah } & $\mathbf{3 8 2}$ \\
Rata-rata PCI = Total Nilai & $\mathbf{7 6 , 4}$ \\
PCI/Jumlah Segmen & \\
\hline
\end{tabular}

Sumber: Hasil Analisis (2016)

Rata - rata PCI yang diperoleh kemudian dimasukkan ke dalam penilaian kondisi jalan dan rating sehingga didapatkan tingkat kerusakan jalan. Nilai rata - rata PCI sebesar 76,4 dan didapat kondisi sangat baik (very good), sehingga untuk penentuan skala prioritas yang diutamakan dalam penanganan kerusakan jalan pada jalan Provinsi Di Kabupaten Lamongan, sebagai berikut:

Tabel 21. Urutan Skala Prioritas Kerusakan Jalan Provinsi di Kabupaten Lamongan

\begin{tabular}{lcc}
\hline Nama Jalan & $\begin{array}{c}\text { Nilai Rata- } \\
\text { Rata PCI }\end{array}$ & Prioritas \\
\hline 1. Jalan Lamong Rejo & 60,75 & Sedang \\
2. Jalan Achmad & 74 & Rendah \\
Dahlan & 76 & Rendah \\
3. Jalan Sunan Drajat & 76,4 & Rendah \\
4. Jalan Raya Mantup & & \\
\hline
\end{tabular}

Sumber: Hasil Analisis (2016)

Dari hasil analisis dan pembahasan diperoleh bahwa dari klasifikasi kerusakan jalan provinsi di Kabupaten Lamongan yang disesuaikan dengan nilai PCI (Pavement Condition Index) serta kondisi jalannya baik. Dalam skala prioritas untuk penanganan kerusakan jalan menggunakan Metode Bina Marga dimana perhitungannya menggunakan volume lalu lintas harian rata - rata, serta kelompok penanganannya dibagi menjadi 3 yaitu: pemeliharaan rutin, pemeliharaan berkala, dan rehabilitas jalan serta peningkatan jalan. Strategi penanganannya melihat dari kondisi urutan skala prioritas, sehingga dapat diharapkan meningkatkan kualitas kondisi perkerasan jalan provinsi di Kabupaten Lamongan. Berikut ini adalah klasifikasi kerusakan jalan, urutan prioritas nilai PCI dan cara perbaikannya, yaitu:

Jalan Lamong Rejo, titik kerusakan paling tinggi yaitu kerusakan berlubang sebesar 33\% dan retak pinggir sebanyak 33\%. Pada kerusakan jalan berlubang untuk perbaikannya dilakukan penambalan diseluruh kedalaman dan untuk kerusakan retak pinggir dilakukan dengan pembongkaran material yang buruk dan diganti dengan material yang baik yang dipadatkan, serta penutupan pada retakan atau pada permukaan.

Jalan Jalan Achmad Dahlan, terdapat 2 titik kerusakan retak pinggir sehingga perlu adanya penutupan pada bagian retakan. Kondisi jalan Achmad Dahlan sangat baik dengan nilai 74 , sehingga program pemeliharaan rutin dengan pemeliharaan preventif yang bertujuan untuk memperpanjang umur perkerasan dan untuk mencegah atau kemungkinan kerusakan akan berlanjut serta perawatan permukaan dan menutup permukaan.

Jalan Sunan Drajat, terdapat 6 titik kerusakan retak buaya, sehingga untuk perbaikannya diperlukan penutupan pada retakan dan perbaikan pada tambalan diseluruh kedalaman untuk perbaikan permanen, serta pembongkaran dan penambalan pada bagian yang rusak.

\section{KESIMPULAN}

Klasifikasi jenis kerusakan jalan berupa rusak ringan yaitu alur, ambles, mengembang, retak melintang/memanjang, retak blok, retak reflek. sambungan, jalur/bahu jalan turun, butiran lepas, agregat licin, tambalan dan persilangan jalan rel. Kondisi kerusakan jalan sedang yaitu retak pinggir, serta kerusakan jalan berat yaitu retak kulit buaya, dan lubang. Nilai PCI kerusakan jalan sedang terdapat pada Jalan Babat - Batas Kabupaten Jombang dengan nilai 52,9, untuk jalan baik terdapat pada Jalan Lamong Rejo nilai 60,75, Jalan Batas Kota Lamongan - Batas Kabupaten Mojokerto 58,1, dan untuk jalan sangat baik pada Jalan Raya Mantup nilai 76,4, Jalan Achmad Dahlan nilai 74, Jalan Sunan Drajat nilai 76.

Penentuan skala prioritas penanganan jalan provinsi di Kabupaten Lamongan diurutkan berdasarkan penilaian kondisi perkerasan yang terkecil, yaitu pada jalan: 1) Jalan Babat - Batas Kabupaten Jombang, 2) Jalan Batas Kota Lamongan - Batas Kabupaten Mojokerto, 3) Jalan Lamong Rejo, 4) 
Jalan Achmad Dahlan, 5) Jalan Sunan Drajat, 6) Jalan Raya Mantup.

Strategi penanganan kerusakan jalan Provinsi di Kabupaten Lamongan berdasarkan pada kondisi kerusakan jalan yang paling banyak terjadi terdiri dari 6 ruas jalan provinsi adalah kerusakan retak buaya sebanyak 49 segmen. Hal ini perlu adanya penanganan dengan penambalan dan pembongkaran di seluruh kedalaman perkerasan serta penutupan pada lapisan permukaan (overlay). Jenis kerusakan jalan yang paling sedikit terjadi adalah rusak pada perpotongan rel terdapat pada 1 segmen jalan.

\section{REFERENSI}

Bolla Evelyn, Margareth. 2011. Perbandingan Metode Bina Marga dan Metode PCI (Pavement Condition Index) dalam Penilaian Kondisi Perkerasan Jalan (Studi Kasus Ruas Jalan Kaliurang, Kota Malang). Malang: Universitas Nusa Cendana.

Christian Pati, Bayu. 2012. Analisis Kerusakan Jalan dan Penanganannya di Kabupaten Lamongan Jawa Timur. Tugas Akhir. Surabaya: Universitas Negeri Surabaya.

Efendi, Muhammad. 2015. Evaluasi Kerusakan Permukaan Jalan Menurut Metode Pavement Condition Index (PCI) (Studi Kasus Ruas Jalan Labu - Langsa - Batas Sumut). Tesis. Banda Aceh: Universitas Syiah Kuala.

Fadli, Achmad., dkk. 2013. Evaluasi Tingkat Kerusakan Permukaan Jalan Isimu Paguyuman Berdasarkan Metode Pavement Condition Index (PCI). Jurnal Teknik Sipil: Universitas Negeri Gorontalo.

Hary Christady H. 2007. Pemeliharaan Jalan Raya. Yogyakarta: Gadjah Mada University Press.

Heriyanto. 2012. Evaluasi Tingkat Kerusakan Jalan dan Prioritas Penanganannya Pada Jalan Propinsi di Wilayah Magetan Jawa Timur. Tugas Akhir. Surabaya: Universitas Negeri Surabaya

Inneke, Widyasari. 2015. Prioritas Penanganan Jalan di Kabupaten Bengkulu Utara. Jurnal Teknik Sipil. Vol III, No. 1 Maret 2015. ISSN: 2339-0271. Surakarta: Universitas Sebelas Maret Surakarta.
Irzami. 2010. Penilaian Kondisi Perkerasan dengan Menggunakan Metode Indeks Kondisi Perkerasan pada Ruas Jalan Simpang Kulim - Simpang Batang. Pekan Baru. Universitas Islam Riau.

Manurung, A, M. 2008. Evaluasi Tingkat Kerusakan Jalan sebagai Dasar Penentuan Perbaikan Jalan. Skripsi. Medan: Universitas Sumatera Utara.

Mardika S, Yeni. 2015. Penentuan Prioritas Perbaikan pada Ruas Jalan WonosariPatemon, Bondowoso. Skripsi. Jember: Universitas Jember

Putri, I Dewa Ayu Ngurah Alit. 2011. Penentuan Skala Prioritas Penanganan Jalan Kabupaten di Kabupaten Bangli. Tesis. Denpasar: Universitas Udayana.

Risdiansyah, M. Isya, dkk. 2014. Studi Penentuan Prioritas Penanganan Ruas Jalan Nasional Bireuen-Lhokseumawe-Pantonlabu. Jurnal Teknik Sipil. Volume 3, No 2, Mei 2014.

Subagio, Bambang., dkk. 2014. Analisis Prioritas Penanganan Perbaikan Jalan pada Perkerasan Kaku Menggunakan Kriteria Kerusakan Pavement Condition Index (PCI). Bandung: Institut Teknologi Bandung.

Sudirman Salatiga. Tesis. Surakarta: Universitas Sebelas Maret Surakarta

Sukirman, Silvia. 1992. Perkerasan Lentur Jalan Raya. Nova: Bandung

Suswandi, Agus, Wardani S., dkk. 2008. Evaluasi Tingkat Kerusakan Jalan dengan Metode Pavement Condition Index (PCI) untuk Menunjang Pengambilan Keputusan. Yogyakarta: Universitas Gajah Mada.

Shahin, M. Y. 1994. Pavement Management for Airport, Road, and Parking Lots, Chapman \& Hall, New York.

Undang-Undang Republik Indonesia Tahun 1945, Pasal 38 PP No. 34 Tahun 2016 tentang Jalan.

Wibowo Arief, Nurchalif. 2011. Evaluasi Kinerja dan Pola Pemeliharaan Jalan Jenderal Sudirman Salatiga. Tesis. Surakarta: Universitas Sebelas Maret. 